\title{
ANALISIS FAKTOR YANG MEMPENGARUHI TRANSFER PRICING PADA PERUSAHAAN MANUFAKTUR DI INDONESIA
}

\author{
Vidiyanna Rizal Putri ${ }^{1}$ \\ STIE Indonesia Banking School \\ Email : vidiputri@ibs.ac.id
}

\begin{abstract}
The aim of this study is to determine and analyze the effect of income tax variables, bonus mechanisms, incentive tunneling to transfer pricing. The sample selection using purposive sampling method and the sample of this research are 23 manufacturing companies listed in Indonesian Stock Exchange (IDX). The data are obtained from secondary data of annual report of basic and manufacture companies listed in Indonesia Stock Exchange in 2012-2016. The analysis technique used in this research is binary logistic regression analysis. The hypothesis in this study is based on previous research and various other supporting theories. The results of this study indicate that the income tax is significant and significant to the transfer pricing, incentive Tunneling influential and significant to transfer pricing, while the bonus mechanism does not affect the transfer pricing.
\end{abstract}

Keywoard: transfer pricing, income tax, Tunneling incentive and bonus mechanism.

\section{Pendahuluan}

\section{Latar Belakang}

Pesatnya pertumbuhan kegiatan ekonomi internasional turut mendorong berkembangnya perusahaan global (Kiswanto dan Purwaningsih 2014). Dalam lingkungan perusahaan dan konglomerasi serta divisionalisasi terjadi berbagai transaksi yang meliputi penjualan barang dan jasa, lisensi hak dan harta tak berwujud lainnya, penyediaan pinjaman dan lain sebagainya yang akan digunakan dalam penentuan harga yang harus ditransfer (Marfuah dan Azizah, 2014).

Transfer pricing merupakan transaksi barang dan jasa antara beberapa divisi pada suatu kelompok usaha dengan harga yang tidak wajar, bisa dengan menaikkan (mark up) atau menurunkan harga (mark down). Ada beberapa tujuan perusahaan indonesia melakukan transfer pricing, pertama, untuk mengakali jumlah profit perusahaan sehingga pembayaran pajak dan pembagian dividen menjadi rendah. Kedua, menggelembungkan profit untuk memoles (window-dressing) laporan keuangan. Negara dirugikan triliunan rupiah karena praktek transfer pricing perusahaan asing di Indonesia, segala cara dilakukan melalui harga penjualan, harga pembelian, overhead cost, bunga shareholderloan, pembayaran royalti, imbalan jasa, penjualan melalui pihak ketiga yang tidak ada usaha (www.pajak.go.id. 2016)

Transfer pricing dilakukan dengan menentukan jumlah penghasilan yang didapat masing-masing perusahaan yang terlibat dan penerimaan pajak penghasilan di negara pengekspor maupun negara pengimpor dan kebanyakan dilakukan oleh perusahaan multinasional (Noviastika, et al., 2016). Adapun fenomena yang terkait transfer pricing di indonesia bahwa $60 \%$ dari wajib pajak di Indonesia melakukan praktik transfer pricing. Hampir semua eksportir di Indonesia melakukan transfer pricing sehingga kerugian negara mencapai $25 \%$ dari nilai eksporan untuk menghindari royalti yang dibayarkan ke negara republik Indonesia (www.ortax.org data diakses pada 1 mei 2017)

Ada beberapa alasan atau faktor perusahaan multinasional melakukan transfer pricing, salah satunya adalah pajak (Noviastika, et al., 2016). Pajak atas 
pengahasilan yang diperoleh atau diterima badan usaha yang bertempatan di indonesia. Besar pengahasilannya bergantung pada jumlah besarnya sebelum pajak (ranawati dan hernawati 2015). Dan dilakukannya dengan cara mengalihkan penghasilan serta biaya suatu perusahaan yang mempunyai hubungan istimewa kepada perusahaan di negara lain yang tarif pajaknya berbeda (Hartati et al., 2015). Hal ini didukung oleh penelitian (Rahayu 2010), ia menemukan bahwa modus transfer pricing dilakukan dengan cara merekayasa pembebanan harga transaksi antar perusahaan yang mempunyai hubungan istimewa. Dengan tujuan untuk meminimalkan beban pajak terutang secara keseluruhan.

Selain itu, mekanisme bonus juga merupakan salah satu faktor yang mempengaruhi transfer pricing. Bonus merupakan pembayaran sekaligus yang diberikan karena memenuhi sasaran kinerja perusahaan (Mispiyanti, 2015). Sistem pemberian bonus ini akan memberikan pengaruh terhadap manajemen dalam merekayasa laba bersih untuk dapat memaksimalkan bonus yang akan mereka terima, termasuk dengan cara melakukan transfer pricing (Hartati et al., 2015).

Tunneling juga berpengaruh terhadap transfer pricing. Tunneling incentive adalah suatu perilaku dari pemegang saham mayoritas yang mentransfer aset dan laba perusahaan demi keuntungan mereka sendiri,namun pemegang saham minoritas ikut menanggung biaya yang mereka bebankan (Hartati et al., 2015). Tunneling dapat berupa transfer ke perusahaan induk yang dilakukan melalui transaksi pihak terkait atau pembagian dividen. Transaksi pihak terkait lebih umum digunakan untuk tujuan tersebut dari pada pembayaran dividen karena perusahaan yang terdaftar di Bursa harus mendistribusikan dividend kepada perusahaan induk dan pemegang saham minoritas lainnya (Yuniasih, et al., 2012).

Hartati, et al., (2014) menguji pengaruh pajak, tunneling incentive dan mekanisme bonus pada keputusan transfer pricing dengan hasil pajak berpengaruh positif dan signifikan terhadap transaksi transfer pricing, tunneling incentive berpengaruh positif dan signifikan terhadap transaksi transfer pricing dan mekanisme bonus berpengaruh positif dan signifikan terhadap transaksi transfer pricing. Nancy (2014) menguji pengaruh pajak, kepemilikan asing, dan ukuran perusahaan terhadap transfer pricing dengan hasil pajak berpengaruh positif terhadap transfer pricing. Wafiroh dan Hapsari (2015) menguji pengaruh pajak, tunneling incentive dan mekanisme bonus pada keputusan transfer pricing dengan hasil pajak berpengaruh positif dan signifikan terhadap transaksi transfer pricing, tunneling incentive berpengaruh positif dan signifikan terhadap transaksi transfer pricing dan mekanisme bonus tidak berpengaruh signifikan terhadap transaksi transfer pricing.

\section{Kajian Literatur}

\section{Landasan Teori}

a. Teori Agensi

Teori agensi menjelaskan mengenai kontrak antara prinsipal, yaitu pihak yang mempekerjakan pihak lain yang disebut dengan agen yang melibatkan pendelegasian pembuatan keputusan (Jensen dan Meckling, 1976). Teori keagenan juga merupakan suatu teori ekonomi yang melatarbelakangi adanya perbedaan konflik kepentingan dalam perusahaan atau organisasi (Lestari dan Wirawati, 2016). Dalam situasi tertentu, baik prinsipal maupun agen akan memaksimalkan kepentingan pribadinya dan tidak ada alasan bagi prinsipal untuk percaya bahwa agen akan selalu bertindak sesuai dengan kepentingan prinsipal (Scott, 2012). Manajemen selaku agen lebih mengutamakan kepentingannya dibanding kepentingan pemegang saham dan karena manajemen diberikan wewenang untuk mengelola aktiva perusahaan sehingga manajemen mempunyai insentif melakukan transfer pricing dengan tujuan untuk menurunkan 
pajak yang harus dibayar (Yuniasih et al., 2012).

\section{b. Transfer Pricing}

Terdapat berbagai macam definisi mengenai transfer pricing yang dikemukakan seperti halnya menurut Suandy (2006) transfer pricing adalah tindakan mengalokasikan laba dari entitas perusahaan dengan tujuan untuk meminimalisir bahkan menghidari pajak. Selanjutnya menurut Fuadah (2008) transfer pricing juga bisa disebut dengan intracompany pricing, intercorporate pricing, interdivisional atau internal pricing yang merupakan harga yang diperhitungkan untuk keperluan pengendalian manajemen atas transfer barang dan jasa antar anggota (grup perusahaan).

\section{c. Pajak Penghasilan}

Pajak penghasilan (PPH) badan yaitu Pajak atas pengahasilan yang diperoleh atau diterima badan usaha yang bertempatan di indonesia. Besar pengahasilannya bergantung pada jumlah besarnya sebelum pajak (ranawati dan hernawati 2015).Aditama dan Purwaningsih (2014) Pajak merupakan salah satu sumber yang penting bagi penerimaan negara guna pembiayaan pembangunan negara. Salah satu sektor pajak yang paling besar diperoleh negara adalah pajak penghasilan.

\section{d. Mekanisme Bonus}

Agar manajer termotivasi mau bekerja lebih baik dan keras maka pemilik menjanjikan sejumlah bonus yang akan diberikan apabila kinerja yang dicapainya di atas rata-rata periode sebelumnya (Sulistyanto, 2008). Mekanisme bonus adalah salah satu kebijakan dalam akuntansi yang populer untuk meningkatkan kinerja direksi dalam meningkatkan laba perusahaan dan ini dapat memaksimalkan penerimanaan kompensasi bonus kepada direksi atas hasil kinerja yang baik terhadap perusahaan, karena menyangkut kesejahteraan para eksekutif di internal perusahaan (Gayatrie 2014).

\section{e. Tunneling incentive}

Tunneling incentive adalah suatu perilaku dari pemegang saham mayoritas yang mentransfer aset dan laba ke perusahaan untuk kepentingan mereka sendiri, namun pemegang saham minoritas ikut menanggung biaya yang mereka bebankan (hartati et al., 2015). Pemindahan aset dan laba dapat dilakukan dengan berbagai cara, salah satunya adalah dengan melalui transfer pricing (noviastika et al., 2016) Transaksi ini digunakan untuk tujuan demi meningkatkan keuntungan laba pemegang saham mayoritas Menurut Wafiroh dan Hapsari (2015).

\section{Perumusan Hipotesis}

a. Pengaruh Pajak penghasilan terhadap Transfer Pricing

Di Indonesia, perusahaan multinasional tidak luput dari rekayasa transfer pricing, alasannya perusahaan melakukan transfer pricing adalah salah satunya untuk menekan beban pajak yang semakin besar karena dalam praktik bisnis, umumnya pengusaha mengidentikkan pembayaran pajak sebagai beban sehingga akan senantiasa berusaha untuk meminimalkan beban pajak tersebut (Mispiyanti, 2015). Apabila pajak dapat ditekan, maka dapat mengurangi cost perusahaan (Marfuah dan Azizah, 2014).

Beban pajak yang semakin besar memicu perusahaan untuk melakukan transfer pricing dengan harapan dapat meminimalkan beban pajak perusahaan yang harus dibayarkan kepada negara tujuannya untuk mengoptimalkan peningkatan laba perusahaan. Berdasarkan rumusan di atas maka hipotesis dalam penelitian ini adalah sebagai berikut.

$\mathrm{Ho}_{1}$ : Pajak tidak berpengaruh terhadap transfer pricing

$\mathrm{Ha}_{1}$ : Pajak berpengaruh terhadap transfer pricing 
b. Pengaruh Mekanisme Bonus terhadap Transfer Pricing

Para direksi dalam menjalankan tugasnya cenderung ingin menunjukkan kinerja yang baik kepada pemilik perusahaan atau pemegang saham. Pemilik perusahaan dan pemegang saham dalam menilai kinerja para direksi biasanya melihat laba perusahaan secara keseluruhan yang dihasilkan atas kinerja direksi. Jika semakin besar laba perusahaan yang dihasilkan maka pemilik perusahaan akan memberikan penghargaan kepada direksi yang telah mengelola perusahaannya dengan baik.

Berdasarkan rumusan di atas maka hipotesis dalam penelitian ini adalah sebagai berikut.
$\mathrm{Ho}_{2}$ : Mekanisme bonus tidak berpengaruh terhadap transfer pricing

$\mathrm{Ha}_{2}$ : Mekanisme bonus berpengaruh terhadap transfer pricing

\section{c. Pengaruh Tunneling Incentive terhadap Transfer Pricing}

Jika pemilik saham mayoritas mempunyai kepemilikan yang besar, dengan kata lain mereka telah menanamkan modal yang juga besar ke dalam perusahaan tersebut. Maka otomatis mereka juga menginginkan pengembalian atau dividen yang besar pula. Untuk itu ketika dividen yang dibagikan perusahaan tersebut harus dibagi dengan pemilik saham minoritas, maka pemilik saham mayoritas lebih memilih untuk melakukan transfer pricing dengan cara mentransfer kekayaan perusahaan untuk kepentinganya sendiri dari pada membagi dividennya kepada pemilik saham minoritas. Oleh sebab itu, semakin besar kepemilikan pemegang saham maka akan semakin memicu terjadinya praktik transfer pricing (Hartati et al., 2015)
Berdasarkan rumusan di atas maka hipotesis dalam penelitian ini adalah sebagai berikut.
$\mathrm{Ho}_{3}$ : Tunneling Incentive tidak berpengaruh terhadap transfer pricing

$\mathrm{Ha}_{3}$ : Tunneling Incentive berpengaruh terhadap transfer pricing

\section{Metode Penelitian}

Populasi dalam penelitian ini adalah seluruh perusahaan manufaktur. penelitian ini peneliti menggunakan perusahaan manufaktur pada tahun 2013-2017 untuk membedakan dari sampel penelitian terdahulu. Teknik sampling menggunakan metode purposive sampling. Purposive sampling adalah teknik penentuan sampel dengan pertimbangan tertentu (Sugiyono, 2012).

\section{Operasionalisasi Variabel Penelitian}

a. Variabel Dependen

Variabel dependen yang diteliti dalam penelitian ini adalah Transfer pricing. Transfer Pricing adalah transaksi harga yang terkandung pada setiap produk atau jasa dari satu divisi ke divisi lain dalam perusahaan yang sama atau antar perusahaan yang mempunyai hubungan istimewa. Transfer pricing dihitung dengan pendekatan dikotomi, yaitu dengan melihat keberadaan penjualan kepada pihak yang mempunyai hubungan istimewa. Perusahaan yang melakukan penjualan kepada pihak yang mempunyai hubungan istimewa diberi nilai 1 dan yang tidak diberi nilai 0. (Hartati et al., 2015).

b. Variabel Independen

1) Pajak Penghasilan

Pajak dalam penelitian ini merupakan pajak pengahsilan oleh badan merupakan kontribusi wajib kepada negara dan bersifat memaksa berdasarkan undang-undang, dengan tidak mendapatkan 
imbalan secara langsung dan digunakan untuk keperluan negara bagi sebesar-besarnya kemakmuran rakyat. Pajak dalam penelitian ini diproksikan dengan effective tax rate yang merupakan perbandingan tax expense dikurangi deferred tax expense dibagi dengan laba kena pajak (Yuniasih et al., 2012).

Effective tax rate $=\frac{\text { tax expense-deferred tax expense }}{\text { laba kena pajak }}$

2) Mekanisme Bonus

Bonus merupakan pembayaran sekaligus yang diberikan karena memenuhi sasaran kinerja perusahaan. Bonus yang diberikan perusahaan dapat berupa tunjangan, komisi, insentif penjualan, atau kesejahteraan karyawan. Pemberian kompensasi bonus diukur dengan dummy, dimana nilai 1 diberikan untuk perusahaan dengan kepemilikan asing yang melakukan pemberian bonus, tantiem,komisi, atau insentif penjualan kepada manajemen, sedangkan yang lainnya nilai 0 .

3) Tunneling Incentive

Tunneling incentive adalah suatu perilaku dari pemegang saham mayoritas yang mentransfer aset dan laba ke perusahaan untuk kepentingan mereka sendiri, namun pemegang saham minoritas ikut menanggung biaya yang mereka bebankan (hartati et al., 2015). Tunneling dapat berupa transfer ke perusahaan induk yang dilakukan melalui transaksi pihak terkait atau pembagian dividen (Yuniasih, et al., (2012)
Variabel ini diukur dengan menggunakan persentase kepemilikan saham di atas $20 \%$ sebagai pemegang saham pengendali oleh perusahaan asing.

\section{Model Penelitian}

Jadi model regresi yang digunakan dalam penelitian ini adalah sebagai berikut:

$\operatorname{Logit}(Y)=\ln [=\beta 0+\beta 1 X 1+\beta 2 X 2+$ B3X3 $+\mathrm{e}$

Keterangan:

$\mathrm{Y} \quad=$ Transfer pricing

$\beta 0=$ Konstanta

$\beta 1-\beta 3=$ Koefisien Regresi

$\mathrm{X} 1=$ Pajak

$\mathrm{X} 2=$ Mekanisme Bonus

$\mathrm{X} 3=$ Tunneling incentive

e $\quad=$ Erro TERM, yaitu tingkat kesalahan penduga dalam penelitian

\section{Hasil dan Pembahasan}

\section{Analisis Dan Pembahasan Hasil Penelitian}

a. Statistik Deskriptif

Statistik deskriptif menunjukan nilai minimum, maksimum, mean dan std. deviation pada setiap variable. ada table 4.3 terdapat variabel dependent yaitu Transfer Pricing dan variabel independent yaitu Pajak Penghasilan, Mekanisme Bonus dan Tunneling Incentive.berikut hasil yang didapet dari variable independent dan dependent Transfer Pricing adalah transaksi yang terkandung pada satu divisi ke divisi lain dalam perusahaan yang sama atau antar perusahaan yang mempunyai hubungan istimewa. Pada variable dependent ini terdapat nilai dari hasil analisa deskriptif yaitu nilai minimum sebesar 0 , nilai maksimum 1 , nilai mean 0.7872 dan nilai std. deviasi sebesar 0.41146. Pajak penghasilan merupakan pajak pengahsilan oleh badan merupakan kontribusi wajib kepada negara dan bersifat memaksa berdasarkan undangundang, dengan tidak mendapatkan 
imbalan secara langsung dan digunakan untuk keperluan negara bagi sebesarbesarnya kemakmuran rakyat. Pada variable independent ini terdapat nilai dari hasil deskriptif yaitu nilai minimum sebesar 0,03 nilai maksimum 0,25 nilai mean 0.2174 dan nilai std. deviasi sebesar 0.4308. Mekanisme Bonus merupakan imbalan dari hasil kinerja atas pencapaian target perusahaan, dan perusahaan memberikan dengan berupa tunjangan, komisi penjualan dan kesejahteraan karyawan. Pada variable independent ini terdapat nilai dari hasil analisa deskriptif yaitu nilai minimum sebesar 0 , nilai maksimum 1, nilai mean 0.5532 dan nilai std. deviasi sebesar 0.49983. Tunneling Incentive merupakan suatu perilaku dari pemegang saham mayoritas yang mentransfer aset dan laba ke perusahaan untuk kepentingan mereka sendiri. Pada variable independent ini pada terdapat nilai dari hasil analisa deskriptif yaitu nilai minimum sebesar 0 , nilai maksimum 0.98 , nilai mean 0.5269 dan nilai std. deviasi sebesar 0.29182 .

b. Uji Multikolinearitas

Tabel Uji Multikolinearitas

\begin{tabular}{cccc}
\hline & TAX & TUNN & BONS \\
\hline TAX & 1 & & \\
TUNN & 1.199 & 1 & \\
BONS & 0.021 & 0.424 & 1 \\
\hline
\end{tabular}

Hasil uji menggunakan SPSS ini adalah tidak terdapat masalah multikolinearitas, sehingga hasil pengujian dikatakan reliabel atau terpercaya. Maka nilai koefisien regresi parsial dikatakan handal dan robust atau kebal terhadap perubahan-perubahan yang terjadi pada variabel lainnya di dalam model regresi berganda.

c. Uji Overall Test 1

menunjukkan perbandingan nilai antara -2 log likelihood blok awal dengan -2 log likelihood blok akhir. Dari hasil perhitungan nilai -2 log likelihood terlihat bahwa nilai blok awal (Block Number $=0)$ adalah 97.308 dan nilai -2 log likelihood pada blok akhir (Block Number $=1$ ) adalah 85.646, hal itu menunjukan -2 log likelihood mengalami penurunan sebesar 11.662. Dengan adanya penurunan nilai tersebut menunjukkan keseluruhan model regresi logistik yang digunakan adalah model yang baik atau model yang dihipotesiskan fit dengan data (Ghozali, 2013).

d. Goodness of Fit

Tabel Hosmer and Lemeshow Test

\begin{tabular}{cccc}
\hline Step & Chi-Square & df & Sig \\
\hline 1 & 13,492 & 8 & 0,096 \\
\hline
\end{tabular}

Nilai statistik Hosmer and Lemeshow Goodness of fit sebesar 13.492 dengan probabilitas signifikansi 0.096 lebih besar dari 0.05 sehingga Ho tidak dapat ditolak atau diterima karena model regresi mampu untuk menjelaskan data. Berdasarkan penjelasan ini, dapat disimpulkan bahwa model mampu menjelaskan pengaruh pajak penghasilan, Mekanisme bonus dan Tunneling Incentive terhadap Transfer Pricing.

\section{e. Nagelkerke R Square}

Untuk melihat kemampuan variabel independen dalam menjelaskan variabel dependen, digunakan nilai Cox \& Snell R Square dan Nagelkerke $\mathrm{R}$ Square. Nilai-nilai tersebut disebut juga dengan Pseudo R-Square atau jika pada regresi linear (OLS) lebih dikenal dengan istilah R-Square.Nilai Nagelkerke R Square sebesar 0,179 yang menunjukkan bahwa kemampuan variabel independen dalam menjelaskan variabel dependen adalah sebesar 0,181 atau $18,1 \%$ dan terdapat $100 \%-18,1 \%$ $=81,9 \%$ faktor lain di luar model yang menjelaskan variabel dependen.

f. Classification Plot

Classification plot digunakan untuk pengujian yang menilai kecocokan model regresi logistik terhadap data dengan 
melihat besarnya ketepatan klasifikasi data observasi terhadap prediksinya. Nila overall percentage sebesar $76,6 \%$ yang kemudian nilai tersebut mengindikasikan bahwa nilai overall percentage mendekati $100 \%$ yang artinya bahwa hasil menunjukkan model yang digunakan fit terhadap data.

g. Model Regresi Logistik

Tabel

Hasil uji Regresi

\begin{tabular}{ccccc}
\hline Variable coefficient & $\begin{array}{c}\text { Std. } \\
\text { Error }\end{array}$ & Prob & $\operatorname{Exp(B)}$ \\
\hline TAX & -27.909 & 13,83 & 0,044 & 0,0000 \\
BONS & -0.602 & 0,6 & 0,316 & 0,548 \\
TUN & 2,215 & 1,096 & 0,43 & 0,109 \\
C & 9,247 & 3,4 & 0,007 & 10373,5 \\
\hline
\end{tabular}

Sumber : olahan data

Berdasarkan tabel diatas maka model regresi logistik yang terbentuk adalah sebagai berikut:

$\ln [=9.247-27.909 \mathrm{TAX}-0.602 \mathrm{BONS}-$ $2.215 \mathrm{TUN}+\mathrm{e}$

Odds ratio pada penelitian ini digunakan untuk mengukur kecenderungan variabel-variabel independen terhadap audit switching perusahaan Nilai odds ratio pada tabel 4.10 diinterpretasikan sebagai berikut:

1) Pajak penghasilan

Koefisien regresi untuk variabel pajak penghasilan adalah sebesar 27.909. Hal ini menunjukkan nilai odds ratio (peluang) dalam penelitian ini adalah sebesar 0.000 , artinya jika koefisien pajak penghasilan menurun satu satuan, maka kecenderungan perusahaan melakukan transfer pricing akan meningkat 0.000 kali dengan asumsi kondisi variabel lainnya konstan
2) Mekanisme bonus

Koefisien regresi untuk mekanisme bonus adalah sebesar 0.602. Hal ini menunjukkan nilai odds ratio (peluang) dalam penelitian ini adalah sebesar 0.548, artinya jika koefisien mekanisme bonus satu satuan, maka kecenderungan perusahaan melakukan transfer pricing akan meningkat 0.548 kali dengan asumsi kondisi variabel lainnya konstan.

3) Tunneling incentive

Koefisien regresiuntuktunneling incentive adalah sebesar 2.215. Hal ini menunjukkan nilai odds ratio (peluang) dalam penelitian ini adalah sebesar 0.109, artinya jika koefisien tunneling incentive menurun satu satuan, maka kecenderungan perusahaan melakukan transfer pricing akan meningkat 0.109 kali dengan asumsi kondisi variabel lainnya konstan.

\section{Analisis Hasil}

a. Pengaruh Pajak Penghasilan terhadap Transfer pricing

Berdasarkan uji di atas, hasil variabel Pajak penghasilan dalam penelitian ini menunjukan berpengaruh negatif dan signifikan terhadap indikasi melakukan transfer pricing pada perusahaan manufaktur yang terdaftar di bursa efek Indonesia hal tersebut ditunjukan dengan hasil koefisien regresi sebesar -21.109 dan probabilitas sebesar 0.044 yang lebih kecil dari tingkat signifikansi sebesar 0,05. Artinya besar atau kecilnya beban pajak mempengaruhi perusahaan manufaktur untuk melakukan tindakan transfer pricing. Hasil ini sesuai dengan penelitian Marfuah dan Winda Hartati, Desmiyawati, Julita (2014) yang menyatakan pajak berpengaruh terhdap transfer pricing dan 
Ni Wayan Yuniasih, Ni Ketut Rasmini dan Made Gede Wirakusuma (2012) yang menyatakan pajak berpengaruh terhadap transfer pricing

Hasil Pajak penghasilan ini juga dikuatkan pada grand teori yang dijelaskan pada agensi teori bahwa agen akan melakukan yang terbaik pada perusahaan terutama dengan meningkatkan laba perusahaan, salah satu caranya dengan melakukan transfer pricing dengan harapan dapat meminimalkan beban pajak perusahaan yang harus dibayarkan, tujuannya untuk dapat mengoptimalkan peningkatan laba perusahaan sehingga agen dapat menunjukan kinerja yang baik kepada pemilik perusahaan.

b. Pengaruh Mekanisme bonus terhadap Transfer pricing

Berdasarkan uji parsial di atas, hasil variabel Mekanisme bonus dalam penelitian ini menunjukan tidak berpengaruh terhadap transfer pricing pada perusahaan manufaktur yang terdaftar di bursa efek Indonesia hal tersebut ditunjukan dengan hasil koefisien regresi sebesar -0.081 dan probabilitas sebesar 0.316 yang lebih besar dari tingkat signifikansi sebesar 0,05. Artinya, jika hanya karena motif untuk mendapatkan bonus, tidak seharusnya direksi berani melakukan transaksi transfer pricing untuk meningkatkan laba perusahaan tetapi direksi dapat melakukan manajemen perusahaan yang baik yang dapat berpengaruh terhadap pencapaian laba yang maksimal, mengingat hal ini sangat tidak etis karna manajemen perusahaan harus menjaga nilai perusahaan dimata masyarakat.

c. Pengaruh Tunneling incentive terhadap Transfer pricing

Berdasarkan uji di atas, hasil variabel Tunneling incentive dalam penelitian ini menunjukan berpengaruh negatif dan signifikan terhadap indikasi melakukan transfer pricing pada perusahaan manufaktur yang terdaftar di bursa efek Indonesia hal tersebut ditunjukan dengan hasil koefisien regresi sebesar -2.215 dan probabilitas sebesar 0.043 yang lebih kecil dari tingkat signifikansi sebesar 0,05 . Artinya bahwa salah satu tujuan dilakukannya transaksi transfer pricing adalah untuk melakukan tunneling kepada pemilik saham minoritas yang mengakibatkan kerugian bagi pihak pemegang saham minoritas. Dan hasil penelitian ini sesuai dengan Mispiyanti (2015) yang menyatakan tunneling incentive berpengaruh terhadap transfer pricing

\section{Implikasi Manajerial}

Pajak penghasilan berpengaruh signifikan terhadap transfer pricing. Hal ini mengidentifikasikan bahwa beban pajak yang semakin besar memicu manajemen perusahaan untuk melakukan transfer pricing melalui transaksi antar divisi atau pihak yang mempunyai hubungan istimewa yang berada diluar Indonesia sehingga laba berkurang dan harapan pajak yang dibayarkan semakin kecil. Tunneling incentive berpengaruh signifikan terhadap transfer pricing, hal ini mengindentifikasikan bahwa pemegang saham pengendali atau pemegang saham mayoritas lebih dapat mendalikan perusahaan untuk kepentingan dan memperkaya mereka sendiri melalui transfer asset perusahaan dan laba perusahaan kepada perusahaan mereka sendiri, dari pada mereka membayar dividen kepada pemegang saham minoritas.

\section{Penutup}

\section{Kesimpulan}

Berdasarkan hasil dari analisis diatas maka dapat disimpulkan bahwa:

a. Pajak penghasilan berpengaruh negatif dan signifikan terhadap transfer pricing.

b. Mekanisme bonus tidak berpengaruh negatif dan signifikan terhadap transfer pricing. 


\section{c. Tunneling incentive berpengaruh negatif dan signifikan terhadap transfer pricing.}

\section{Saran}

a. Keterbatasan dan Saran

Adapun saran yang bisa peneliti berikan berdasarkan penelitian ini adalah sebagai berikut:

1) Variabel penelitian ini hanya meneliti Tax, tunneling insentif dan bonus, diharapkan untuk penelitian berikutnya menambah variabel bebas lain, seperti ukuran perusahaan, exchangerate, Good Corporate Governance (GCG).
2) Objek penelitian ini adalah perusahaan manufaktur, disarankan untuk peneliti selanjutnya meneliti erusahaan yang berjalan disektor pertambangan, perkebunan dan sektor lainnya.

3) Periode waktu penelitian ini hanya 5 (lima) tahun, diharapkan penelitian selanjutnya dapat menambah waktu periode penelitian, karena periode yang lebih panjang diharapkan dapat memberikan hasil yang lebih baik.

\section{Daftar Pustaka}

Aditama, Ferry dan Purwaningsih, Anna. 2014. Pengaruh Perencanaan Pajak Terhadap Manajemen Laba Pada Perusahaan Non Manufaktur Yang Terdaftar Di Bursa Efek Indonesia. Fakultas Ekonomi Universitas Atma Jaya Yogyakarta. Vol.26 (1).

Agnes W. Y. Lo, Raymond M. K. Wong, and Michael Firth, 2010. Tax, Financial Reporting, and Tunneling Incentives for Income Shifting: An Empirical Analysis of the Transfer Pricing Behavior of Chinese-Listed Companies. American Accounting Association Vol. 32, No. 2 .

Banyu Ageng Wahyu Utomo, 2011. Pengaruh Sikap, Kesadaran Wajib Pajak, dan Pengetahuan Perpajakan Terhadap Kepatuhan Wajib Pajak Dalam Membayar Pajak Bumi dan Bangunan di Kecamatan Pamulang Kota Tangerang Selatan. Fakultas Ekonomi dan Bisnis Universitas Islam Negeri Syarif Hidayatullah, Jakarta.

Berita Ditjen Pajak Perketat Aksi Transfer Pricing Yang Dapat Diakses Melalui Http://Www. Ortax.Org Pada Tanggal 1 Mei 2017.

Budiasih, I. G. (2011). Peranan Konservatisme pada Information Assymetry: Suatu Tinjauan Teoritis. Jurnal Ilmiah Akuntansi dan Bisnis, 6(2), 1-16

Direktorat Jenderal Pajak. (2012, Agustus 15). Menangkal Kecurangan Transfer Pricing. Diambil Kembali Dari Http:/Www.Pajak.Go.Id/Content/Article/MenangkalKecurangan-Transfer-Pricing.

Fuadah, Luk Luk. “Analisa Transaksi-transaksi yang Terjadi dalam Masalah Transfer Pricing pada Kasus PT. Asian Agri di Indonesia.” Jurnal Keuangan dan Bisnis 6.2 (2008): 108129.

Gayatrie, R. H. 2014 Skema Bonus Dalam Keputusan Akuntansi Manajer. Politeknik Negeri Semarang.

Gujarati, D. (2007). Dasar-dasar Ekonometrika (3rd ed. ed.). Jakarta: Erlangga 
Ghozali, I. (2013). Aplikasi Analisis Multivariate Dengan Program IBM SPSS 21 Update PLS Regresi. Badan Penerbit Universitas Diponegoro.

Ghozali, I. (2016). Aplikasi Analisis Multivariate Dengan Program IBM SPSS 23.Badan Penerbit Universitas Diponegoro.

Halim, M. L., Wardhani R, 2011. Analisis Pengaruh Konflik Keagenan Terhadap Kebijakan Dividen. Program Studi Akuntansi, Fakultas Ekonomi Universitas Indonesia.

Hartati, Winda., Desmiyawati, dan Julita, 2014. Tax Minimization, Tunneling Incentive dan Mekanisme Bonus Terhadap Keputusan Transfer Pricing Seluruh Perusahaan yang Listing di Bursa Efek Indonesia. Jurnal Simposium Nasional. Universitas Riau.

Jensen, M., \& Meckling, W. (1976). Theory Of The Firm: Managerial Behavior, Agency Costs and Ownership Structure. Journal of Financial Economics 3.

Kiswanto, N. And Purwaningsih, A. 2014. Pengaruh Pajak, Kepemilikan Asing, Dan Ukuran Perusahaan Terhadap Transfer Pricing Pada Perusahaan Manufaktur Di BEI Tahun 2010-2013. Jurnal Universitas Atma Jaya..

Lestari, S. D., \& Wirawati, N. G. (2016). Good Corporate Governance sebagai Pemoderasi Pengaruh Asimetri Informasi pada Manajemen Laba. E-Jurnal Akuntansi Universitas Udayana, 16(1), 156-182.

Marfuah And Azizah, A. P. N. 2014. Pengaruh Pajak, Tunneling Incentive, Dan Exchange Rate Pada Keputusan Transfer Pricing Perusahaan. JAAI Vol 18, No. 2, Desember 2014: 156-165.

Misipiyanti, 2015. Pengaruh Pajak, Tunneling Incentive dan Mekanisme BonusTerhadap Keputusan Transfer Pricing Program Studi Akuntansi, STIE Putra Bangsa

Natakharisma, Vyakana dan Sumadi, I.Kadek. 2014. Analisis Tax Planning Dalam Meningkatkan Optimalisasi Pembayaran Pajak Penghasilan Pada PT. Chidehafu. Jurnal Akuntansi Universitas Udayana, Fakultas Ekonomi dan Bisnis, Bali.

Noviastika, F. D., Mayowan, Y. Dan Karjo, S. 2016. Pengaruh Pajak, Tunneling Incentive Dan Good Corporate Governance (Gcg) Terhadap Indikasi Melakukan Transfer Pricing Pada Perusahaan Manufaktur Yang Terdaftar Di Bursa Efek Indonesia (studi pada bursa efek indonesia yang berkaitan dengan perusahaan asing).

PS Perpajakan, Jurusan Administrasi Bisnis, Fakultas Ilmu Administrasi, Universitas Brawijaya.

Ratnawati, Juli, And Retno Indah Hernawati. Dasar-Dasar Perpajakan. Deepublish, 2016.

Rahayu, Ning. 2010. Evaluasi Regulasi Atas Praktik Penghindaran Pajak Penanaman Modal Asing. Jurnal Akuntansi dan Keuangan Indonesia Vol. 7. No. 1.

Saraswati, Medianti Jipi. "Evaluasi Kewajaran Harga Dan Kesesuaian Metode Transfer Pricing Dengan Perdirjen Pajak Nomor Per-32/Pj/2011 (Studi Kasus Pada Pt. Mertex Indonesia)." Jurnal Mahasiswa Perpajakan 3.1 (2014).

SAS No. 99. Consideration of Fraud in a FinancialStatement Audit. Scott, W. R. (2012). Financial Accounting Theory (6th ed.). United States of America: Pearson Prentice Hall.

Suandy, Erly. 2006. Perencanaan Pajak. Jakarta : Salemba Empat.

Sulistyanto. 2008. -Manajemen Laba: Teori dan Model Empiris\|. Jakarta: PT Gramedia Widiasarana Indonesia 
Sugiyono. (2012). Metode Penelitian Kuantitatif Kualitatif dan R\&D. Bandung: Alfabeta.

Winarno, W. W. (2011). Analisis Ekonometrika dan Statistika dengan EViews. Unit Penerbit dan Percetakan STM YKPN .

Wafiroh, N. L., Hapsari N.N, 2015. Pengaruh Pajak, Tunneling Incentive, Dan Mekanisme Bonus Pada Keputusan Transfer Pricing Perusahaan Manufaktur Yang Listing Di BEI Periode 2011-2013. Jurnal, Universitas Islam Negeri, Malang.

Yuniasih, N. W., Rasmini, N. K. Dan Wirakusuma, M. G. 2012. Pengaruh Pajak Dan Tunneling Incentive Pada Keputusan Transfer Pricing Perusahaan Manufaktur Yang Listing Di BEI. Jurnal Universitas Udayana.

Zain, Mohammad, 2003. Manajemen Perpajakan, Penerbit Salemba Empat, Jakarta. 